\title{
DIGITAL PROMOTION AS SOLUTION FOR INTEGRATED MARKETING COMMUNICATION IN BUSINESS
}

\author{
Santa Bormane ${ }^{1}$, Mg. oec. / Candidate for Doctoral Degree in Economics; \\ Anda Batraga ${ }^{2}$, assoc. prof. / Dr.oec. \\ 1,2 University of Latvia, Faculty of Business, Management and Economics
}

\begin{abstract}
The increasing development of integrated marketing communications, based on the use of the Internet in communication with consumers, the growth of technologies, changes in the form and nature of communication and other trends, enhances the role of digital marketing. The article presents the integrated marketing communications which businesses apply in their marketing strategy and which nowadays require modifications in management. Particular attention is devoted to digital promotion in integrated marketing communication usable as a tool for raising the level of customer attraction and loyalty. The goal of the research was to assess integrated marketing communications in the context of digital promotion.

The research confirmed the initial hypothesis that the use of integrated marketing communications in digital promotion raises the level of consumer involvement and facilitates the exchange of information. There have been conclusions and proposals drawn up based on the results. The study is based on scientific literature and the following quantitative and qualitative methods were used to accomplish the goals and objectives: interrogative, comparative, grouping, graphical, evaluative and descriptive. As part of the research, a poll of leading specialists from Latvian food retail chains was conducted in 2017.
\end{abstract}

Keywords: integrated marketing communication, integrated marketing communication tools, digital promotion, sustainable marketing, sustainable development.

JEL code: M31 Marketing

\section{Introduction}

The use of integrated marketing communications is developing based on the use of the Internet in communication with consumers, the growth of technologies, changes in the form and nature of communication and other trends which enhance the role of digital marketing. Consumers nowadays require a different way of communication that ensures a convenient access to information through various channels at any time and any place with an option to get involved, share and express one's opinion, or join a social group, including listening to opinion leaders etc. Digital promotion as a set of integrated marketing communication measures in the context of sustainability and its use in the marketing strategy contributes to consumer awareness in observing the core conditions of sustainability and to changes in the public thinking and action, boosting not only the company's demand, but also the overall economic development, social responsibility, and environment preservation.

The goal of the research is to assess integrated marketing communications in the context of digital promotion. The object of the research is digital promotion as a set of integrated marketing communication measures, and the subject of the research is digital promotion tools in the marketing strategy of food retail chains. The hypothesis is that the use of integrated marketing communications in digital promotion raises the level of consumer involvement and facilitates the exchange of information. In order to reach the goal, the authors put forward the following objectives - to study integrated marketing communication and its development in digital promotion, to draw up an expert questionnaire for rating digital promotion as a set of integrated marketing communication measures and its impact upon demand at Latvian food retail chains, to conduct an expertise, to collect, analyse and evaluate data using generally accepted quantitative and qualitative methods of economic research - interrogative, comparative, grouping, graphical, evaluative, descriptive. The research is based on scientific papers published by Latvian and foreign 
scholars, general and special literature, periodicals, and the MS Excel software was used for data processing and analysis.

\section{Development of integrated marketing communication}

Sustainable business lies upon management systems and tools that, instead of supporting a neoclassic business, transform it, with an increasing consideration of social and environmental factors. More and more companies face "the challenge of encompassing sustainability in their business, searching for opportunities to integrate in a global sustainable development," according to Sandra Morioka, Steve Evans and Marly Monteiro de Carvalho (2016).

The business management systems and their tools applied by businesses are means that differ in terms of complexity and ease of application and that are used to accomplish business targets, implement business processes, or improve operations. Entrepreneurs adopt a variety of business management tools, as "one cannot apply standardised identical performance criteria to all companies because each company is a universal formation characterised by belonging to a specific industry, organisational structure, management style, market share and other distinct features".

Manfred Bruhn and Stefanie Schnebelen (2017) point out that the definition of IMC has evolved and back in 1989 the American Association of Advertising Agencies defined IMC as a concept of marketing communication planning that recognises the added value of advertising agencies in a programme where a variety of strategic disciplines have been integrated - such as general advertisement, direct response, sales promotion and public relations -, by combining them to ensure clarity, consistency and a maximum effect of communication.

Maja Seric, Irene Gil-Saura and Durdana Ozretic-Dosen (2015) describe IMC as "a tactical and strategic consumer-oriented business process which is facilitated by the advancements of information and communication technologies (ICT) and which, based on information obtained from customer databases and through the coordination and synergy of various communication tools and channels, conveys a clear and consistent message to preserve a long-term lucrative relationship with customers and other stakeholders and to build and maintain the brand value".

Jelena Salkovska (2016) maintains that "the essence and process of IMC are related to: 1) the integration of types of marketing communication (advertising, sales promotion, public relations, sponsorship, direct marketing, interactive marketing, personal selling, exhibitions); 2) the integration of distribution channels of marketing communication (TV, press, the Internet, radio, outdoor and other channels); 3) the integration of marketing activities (product, price, distribution and placement, promotion); 4) the integration of market participants (manufacturers, suppliers, brokers, partners, direct marketing participants, consumers/buyers)".

Pursuant to this development, IMC is defined as a strategic and operational process that includes analysis, planning, organisation, implementation and supervision and is aimed towards distributing a concerted and consistent image of a company or a reference object by integrating the company's special sources of internal and external communications (Bruhn, M., 2008). Hence, the functions of IMC extend far beyond a mere integration and merging of communication activities in form (i.e. compliance with formal design principles such as fonts, sizes, colours, core visual parameters), time (i.e. coordination of communication activities within and beyond planning periods) and content (thematic coordination by connection lines such as messages, arguments and statements) - it focuses on the management process for the integration of internal and external communication. 
The evolution of the definition of IMC is related to its conceptual development which took place in the USA and Europe simultaneously, yet independently. The discussion of the progress of IMC in the scientific literature is based on six core aspects of content of the concept: 1) theoretical grounds where IMC concepts are based on communication and social science theories, the organisational theory, and others; 2) communication tools considering what mass media each IMC concept is oriented towards and what mass media it encompasses; 3) planning process, indicative whether the concept is based on a comprehensive and strategic planning process; 4) organisational and personnel aspects, indicative whether there are solutions offered for structural and/or processoriented organisational and personnel issues in relation to IMC; 4) relationship orientation and online communications; 6) social media involvement (Bruhn, M., 2014).

Arvydas Bakanauskas (2004) opines that the communication process begins when two or more people (sender and recipient) come into contact directly or through such means as telephone, television, the Internet etc. and continue until the contact is terminated. One may have interest, which is affected by the other, and an intention to send him information. The goal is to make the other participant of the process receive and understand the information and react the way the sender wants him to.

Salkovska (2016) also notes that "in practice there are no strict borders between the two groups. For instance, advertisement (a TV ad with immediate response) or sales promotion (a client card) may be personal, and vice versa - direct marketing may end up mass in scale (for instance, due to ineffective use of a database). As concerns interactive marketing, the scale of its communication - personal or mass - entirely depends on the information sender's decision (for instance, an e-mail message is personal, but a regular banner is mass communication). However, the overall development trend of the marketing communication system, in the book authors' opinion, lies in an increased role of personal communications."

The idea of a concerted use of different marketing communication tools has become a recognised practice in the industry. With the evolution of IMC in progress, in the scientific literature the IMC paradigm has been addressed separately: 1) Kenneth E. Clow and Donald E. Baack (2002) treat IMC as an information technology system that enables storage and manipulation of voluminous customer data; 2) Anders Gronstedt (1997) presents it as using the Internet as information source, communication channel, deal facilitator and distribution tool; 3) Philip J. Kitchen and Don Edward Schultz (1997) discuss IMC as growth of the agency practice internationalisation, globalisation, customer reflection, organisational learning and practice driven by customer needs, multi-country, multi-office structures and networks; 4) Ali Kanso and Richard Alan Nelson (2002) see IMC as a need for brands to become global and highlight it as advertisement localisation pressure; 5) Kitchen and Schultz (2000) find that "since the world has changed, so have the nature and forms of communication, therefore the practice of development and management of marketing and communications should change as well".

All these changes have been used to support the argument of the development of IMC. The early literature testified that IMC had aroused substantial interest in the marketing world. The article by Clark L. Caywood, Don Edward Schultz and Paul Wang (1991) suggests that most of the issues, philosophies and arguments covered are about 10 years old, so this is a relatively new and dynamic area of research, possibly still at the stage of early growth.

The development of the use of IMC is helped by the increased use of the Internet in communication with consumers, the development of technologies, changes in the form and nature 
of communication and other trends that enhance the role of digital marketing. Integrated marketing communications, which businesses apply in their marketing strategy, require modifications in management, with digital promotion playing a key role in integrated marketing communications. For instance, a customer looking for a camera may do the information searching and consideration of alternatives in respect of the said product, or receive an attractive offer, go to the shop and take advantage of it. This is why online activities on Facebook, Twitter, YouTube or similar sites make a good communication platform, reaching the customer at any time and place and drawing attention through the interactive form of presentation. Still, as pointed out by Ake Finne and Christian Gronroos (2017), the perception of a given camera brand might be based on previous experience, probably from borrowing one, which has been positive. In such cases the communication process does not include a company source.

Over the years, the essence of IMC has expanded depending on what needs to be integrated and who integrates (Kitchen, P., Kim, I., Schultz, D., 2008). The traditional school of communication has long been criticised for the passive vision of customer (Buttle, F., 1995). While researchers pay more attention to the integration of customers, the body to be integrated is still largely company-oriented and based on traditional communication tools (Pelsmacker, P. , Geuens, M., Van den Berg, J., 2013). Businesses now need to listen to their customers, find real points of interface with customers, and understand them, thus recognising and creating messages corresponding to the importance and value of customers. A customer can passively watch a televised advertisement whilst searching on Google or Wikipedia and sending messages on Facebook and chat rooms. Meaning-based communication models (Mc Cracken, G., 1986) are one way how to place an active customer in the centre of the process. However, a key role in the development of IMC is played by digital promotion which gives vast options to businesses and consumers alike.

The authors find that a variety of IMC digital promotion tools may be used for a company's development and implemented through its website. For instance, in the context of sustainability, the company could adjust the structure of the information available on its website, with ecological products or Latvian-made products singled out, or offer a mobile application with information on the availability of such products to promote them. It would not cost much for them, as posting information on the Internet merely takes some time from the staff.

Information contained by the product barcode on the disposal and reuse of product packaging and the health impact of product composition and quality, as well as pictures on general use, in the author's view, would be a useful tool to be implemented by product manufacturers if they were required to do so by the Latvian legislation.

The formation of online social groups of consumers who regularly buy ecological products and their involvement in the popularisation, evaluation and promotion of the company's website, social media profiles and products, with the consumer activities rewarded based on a game system, would be effective as well. Social media and the latest technologies enable businesses to communicate with masses - a large number of people, and people are inherently interested in games and other exciting activities, so this would promote loyalty and raise the company's popularity. A game element system, linked to the brand loyalty programme to promote the sales of ecological products, could be implemented using points, discounts or gifts, and draw consumers long term. 
The authors would also like to mention IMC tools for sustainability pertaining to loyalty cards and their linkage to payment, account replenishment and budget planning options. While these days there are plenty of loyalty cards and it may be inconvenient for consumers to carry multiple cards, businesses could use technologies to enhance their functionality and implement their marketing activities through these tools using direct marketing, offering products suited to each individual's habits and drawing buyers long term. If the company finds out the consumers' habits, offers him a budget planner and food basket based on his previous purchases and sets up a system that enables payment via loyalty card, the consumer will be less sensitive to price fluctuations generated by competitors and sales promotion activities involving price changes or gifts for purchase, just because he will have funds on the loyalty card - a certain amount that can only be spent at a certain shop - and will be able to replenish the card as well.

\section{Practical study on digital promotion in integrated marketing communication}

Concurring in essence with the development of integrated marketing communications in the context of digital promotion, the authors put forward a hypothesis that the use of integrated communications in digital promotion raises the level of consumer involvement and facilitates the exchange of information. In order to confirm or reject the hypothesis, the authors conducted research to assess the use of IMC at Latvian food retail chains. In order to study the influence of IMC digital promotion upon demand, an expert questionnaire was drawn up. The expert poll was held in 2017, and the MS Excel software was used for data aggregation and analysis. The goal of the poll was to find out the influence of IMC upon demand, with merchandising singled out.

According to the results of the expert poll (Figure 1), demand is increased by the following IMC digital promotion-related tools: company website design, ease of use, structure; company website providing information about shop and its products, and option for consumers to receive information and follow company on social media. Meanwhile such IMC tools as mobile application for convenient online shopping or providing information about shop and its products are absent from the companies' marketing communication. The authors find the trends of development in digital promotion to be positive - the expert ratings show that businesses do use digital promotion in their marketing communication and the authors agree that the website and its information is the company's business card that builds the first impressions on the company and its products. More extensive and structured information on the website is a relatively cheap way of communication yet yields many benefits - the availability of information to a vast range of consumers, the options of sharing information on social media facilitate communication among consumers, as well as information movement towards masses, hence the company can raise the level of consumer loyalty based on the information provided on the website. 


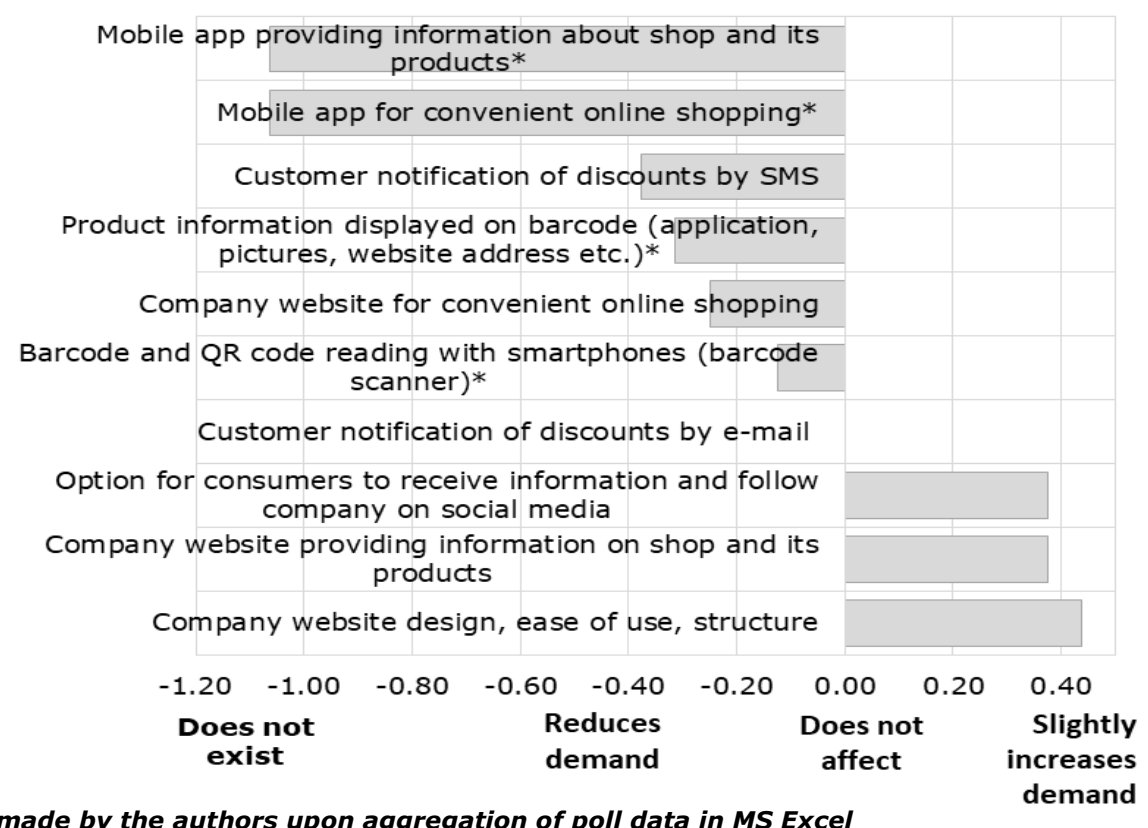

Source: figure made by the authors upon aggregation of poll data in MS Excel

Fig. 1. Impact of IMC digital promotion-related tools upon demand, average expert ratings

Meanwhile the creation of online social groups enables the company to communicate with masses.

The authors mark out that businesses currently do not apply such IMC tools as mobile application for convenient online shopping or providing information about shop and its products, so there is room for growth. The authors find that not all Latvian food retail chains have online shops and for some such marketing activities are therefore not applicable.

Still, the authors recommend for those retail chains that have online shops to develop mobile applications as a competitive advantage, given the success examples of the availability of main banking services through a mobile application, an application of the Latvian State Revenue Service for declaring the eligible expenditure for tax purposes, an application for paying for a parking lot, an application for travellers, navigation and traffic information, applications that help people live a healthy and active life etc. Mobile applications help maintain a high level of loyalty of the consumers involved, as the convenience and privacy in an individual's phone may contribute to a decision in favour of a given shop. Furthermore, applications enable creating consumer databases, making customised loyalty programmes and offers for specific social groups to implement a customer-oriented approach.

As concerns IMC digital promotion-related tools in the context of sustainability, the expert poll reveals (see Figure 2) a partial presence of such marketing communications as formation of social groups on social media for consumers who buy ecological products, involvement of consumers in popularisation, evaluation, promotion of company's products on website, social media etc. (reward for consumer activities - game system), mobile application with information on Latvian-made products available in store, mobile application with information on ecological products available in store, linkage of loyalty card to payment options, account replenishment options, and other IMC digital promotion tools.

The authors concede that IMC digital promotion-related tools for sustainability are new and do not exist in the marketing communication of retail chains by now. As stated before, the development of technologies, including the use of smartphones, may serve as basis for businesses 
to involve consumers in the promotion of their website and the popularisation of their products through social media, thus stimulating the exchange of information among masses. In order for this IMC activity to yield benefits, the authors recommend linking it with a system of consumer activity reward or games and points. Consumers like engaging in various games that motivate, incite action, and the reward system helps maintain the involvement and attention of consumers for a longer period.

Such IMC tools as mobile application with information on Latvian-made products available in store and mobile application with information on ecological products available in store, as stated before, may also be used for the implementation of a sustainable marketing strategy. The use of digital marketing to bring information to consumers and emphasising the availability of Latvianmade products and ecological products enable food retail chains not only to popularise their assortment, but also to promote the consumption of domestic and ecological products.

Linkage of loyalty card to payment options and account replenishment options, in turn, would help increase the number of loyal customers. The authors believe that, with consumers having loyalty cards, the linkage of such cards to payment options could sway them towards visiting the particular food retail store, and the option of replenishing the loyalty card account with own funds would directly attract consumers to that retail chain. Hence, there is a likelihood of holders of such cards being less sensitive to competitors' marketing activities, especially those with an immediate effect, sales promotion measures primarily pertaining to price or some further benefits - gifts, souvenirs etc. 
Information on company's website on Latvian-made products a vailable in store

Structure of information available on company's website with ecological and Latvian-made products singled out

Information on company's website on ecological products available in store

Linkage of loyalty card to budget planning options

Involvement of consumers in popularisation, evaluation, promotion of company's products on website, social media etc. (reward for consumer activities - game system)

Linkage of loyalty card to payment options, account replenishment options

System of game elements linked to brand loyalty programme to promote sales of ecological products (points, discounts, gifts, status)

Formation of social groups on social media for consumers who regularly buy ecological products

Mobile app with information on ecological products available in store

Mobile app with information on Latvian-made products available in store

Mass involvement in new product creation

Information within product barcode on disposal and recycling of product packaging, impact of composition and quality on health, pictures on general application

$\begin{array}{ccccc}0,00 & 0,40 & 0,80 & 1,20 \\ \begin{array}{c}\text { Does not } \\ \text { affect }\end{array} & \begin{array}{c}\text { Slightly } \\ \text { increases } \\ \text { demand }\end{array} & \begin{array}{r}\text { Substantially } \\ \text { increases } \\ \text { demand }\end{array}\end{array}$
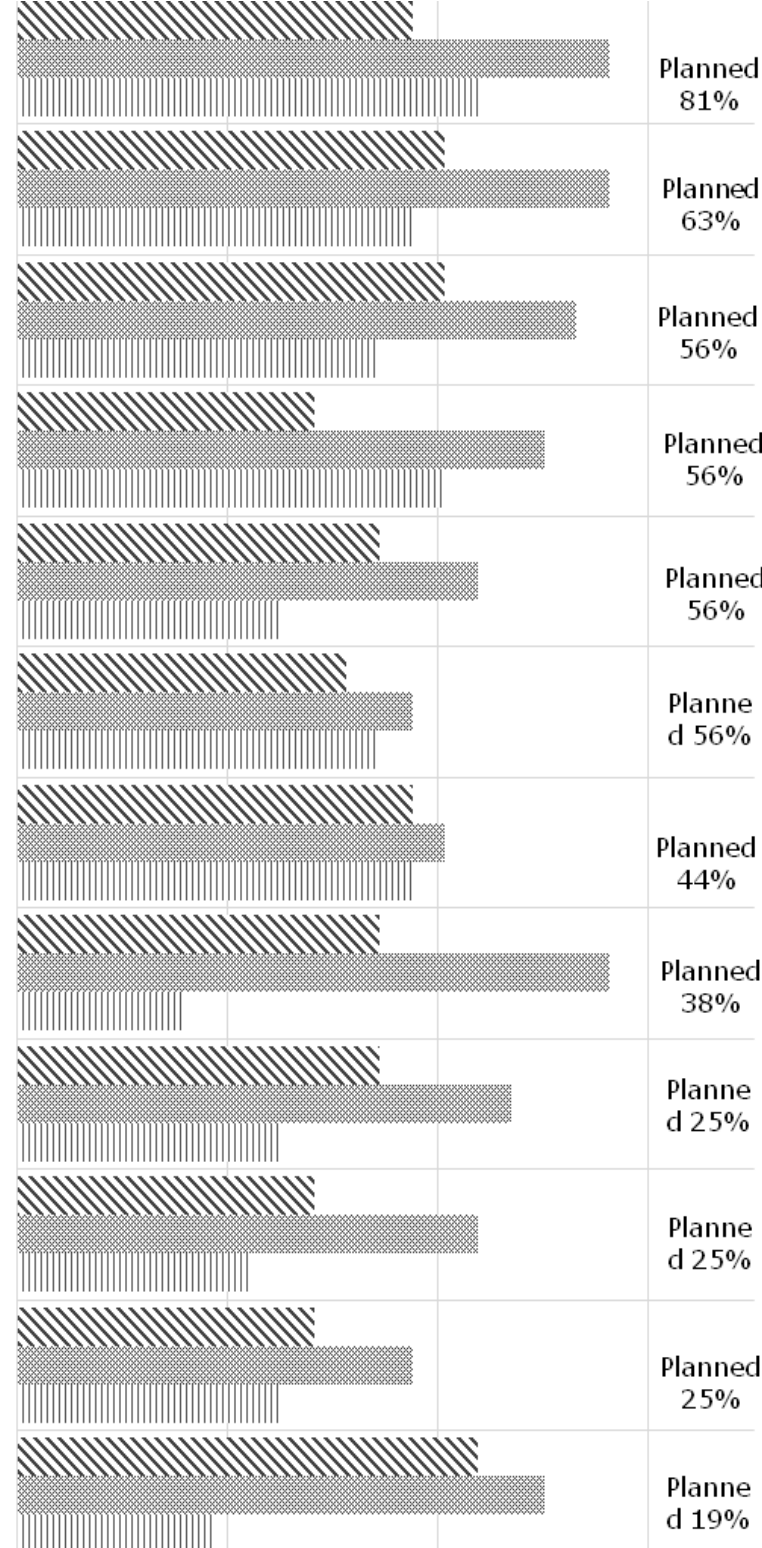

Source: Figure made by the authors upon aggregation of poll data in MS Excel

Fig. 2. Impact of IMC digital promotion-related tools for sustainable upon Latvia's sustainable development

According to the results of the expert poll (Figure 2), within the next 3 years the food retail chains intend to use IMC digital promotion-related tools in their marketing strategy in the context of sustainability, despite many of those tools being new and not applied in practice so far. The authors welcome the expert replies as to which IMC digital promotion-related tools businesses intend to use in their marketing strategy. Company website and its information is, in essence, a relatively cheap communication channel. The availability of information on the website not only provides consumers with information but also builds the company's identity. It is the website 
information on ecological or Latvian-made products that constitutes grounds for the integration and promotional use of such IMC digital promotion tool as involvement of consumers in popularisation, evaluation, promotion of company's products on website, social media etc. (reward for consumer activities - game system). As noted before, the involvement of consumers in popularisation activities through a motivational game programme enables businesses to expand the range of their loyal customers, with an impact upon regular revenues. A loyal customer is each company's regular source of revenue and basis of business. It is only the number of loyal customers that a company can base its future sales plans and resource requirements upon.

However, while part of the companies intends to use the specified IMC digital promotion-related tools for sustainability in their marketing strategy within the next 3 years, the experts have rated these IMC digital promotion-related tools as conducive to economy, social responsibility and environment (see Figure 2), with a positive impact upon the sustainable development of Latvia. This notably applies to information for consumers on company websites and makes the tools more influential not only towards increasing demand, but also towards overall developments where consumers, businesses and the state would benefit alike.

The authors explain that the expert replies whereby part of the companies intend to introduce mobile applications in their marketing strategy within the next 3 years stem from the fact that not all retail chains have online shops, so a mobile application would not justify the investment. Yet the authors encourage the chains that have an online shop to not just supplement their website and online shop with a mobile application, but make shopping more convenient. An application might not result in a great number of customers buying products via smartphone, but it allows to notify consumers of product availability as well as to structure products for marketing purposes (e.g., ecological, Latvian-made etc.). Mobile applications also get consumers involved in promotion and cover other functions, with the retail chains thus obtaining consumer data for direct marketing. Consumer data is a valuable resource for the purposes of personalised IMC.

\section{Conclusions}

1) IMC is developing, and digital promotion plays a key role in communication with consumers. Online activities in the media make a good communication platform, as customers can be reached at any time and place and the interactive way of presentation draws attention, encourages involvement, and promotes communication among consumers.

2) The use of digital promotion tools of integrated marketing communication has a positive impact upon demand at Latvian food retail chains.

3) Digital promotion as a set of integrated marketing communication measures in the context of sustainability and its use in the marketing strategy fosters economic development, social responsibility, and environment preservation.

4) The objectives set out for the study have been fulfilled and the goal has been achieved. The theoretical and practical research confirms the initial hypothesis that the use of integrated marketing communications in digital promotion raises the level of consumer involvement and facilitates the exchange of information.

5) Mobile applications get consumers involved the promotion of businesses and their products and enable retail chains to obtain consumer data for a personalised direct marketing. A high level of consumer loyalty, convenience and privacy may be the basis not only for a decision to visit the 
shop, but also for databases, individual loyalty programmes, offers to specific social groups, ensuring a customer-oriented approach.

6) The use of IMC digital promotion with the involvement of consumers in popularisation activities based on a motivational game programme enables businesses to expand the range of their loyal customers, with an impact upon their regular revenues. Based on the number of loyal customers, businesses may plan their future sales volumes, product assortment, resource requirements.

\section{Bibliography}

1. Bakanauskas A., 2004, Marketingo komunikacija. Kaunas: VDU leidykla, p. 78-79

2. Bruhn, M. (2014). Integrierte Unternehmens- und Markenkommunikation: Strategische Planung und operative Umsetzung, Edittion 6th, Schäffer-Peoschel Verlag, Stuttgart, p. 87

3. Bruhn, M.(2008). Planning Integrated Marketing Communications, in Sievert, H. and Bell, D. (Eds), Communication and Leadership in the 21st Century: The Difficult Path from Classical Public Relations to Genuine Modern Communication Management, Bertelsmann Stiftung, Gütersloh, p 13-34

4. Bruhn, M., Schenebelen, S.(2017). Integrated Marketing Communication - From an Instrumental to a Customer-Centric Perspective, European Journal of Marketing, Volume 51, Issue 3, p. 464-489

5. Buttle, F., 1995, "Marketing Communication Theory: What do the Texts Teach Our Students", International Journal of Advertising, Vol. 14 No. 4, pp. 297-313.

6. Caywood, C.L., Schultz, D.E. and Wang, P. (1991). Integrated Marketing Communications: a Survey of National Consumer Goods Advertisers, Unpublished Research Report

7. Ciemleja, G. (2010). The Sustainable Performance of Small and Meduim-Sized Enterprises. Problems and Solutions., Summary of Doctoral Dissertation of Economics and Management, Riga Technical University, pp. 28

8. Clow, K. E., Baack, D. (2002). Integrated Advertising, Promotion and Marketing Communications. Cranbury, $\mathrm{NJ}$ : Pearson Education, Inc.

9. Finne, A., Gronroos, C., 2017, Communication-in-Use: Customer-/Integrated Marketing Communication, European Journal of Marketing, Vol. 51 Issue: 3, p 445-463, pieejams: https://doi.org/10.1108/EJM-082015-0553 [skatīts 10.03.2017.]

10. Gronstedt, A. (1997). Internet: IMC on Steroids, Marketing News, Volume 31, p 16

11. Kanso, A., Nelson, R. (2002). Advertising Localisation Overshadows Standardisation, Journal of Advertising Research, Volume 42, p 79-89

12. Kitchen, P. and Schultz, D., 2009, "IMC: New Horizon/False Dawn for a Marketplace in Turmoil", Journal of Marketing Communications, Vol. 15 Nos 2/3, pp. 197-204.

13. Kitchen, P. , Kim, I. and Schultz, D., 2008, "Integrated Marketing Communications: Practice Leads Theory", Journal of Advertising Research, Vol. 48 No. 4, pp. 531-546.

14. Kitchen, P. J., Schultz, D.E. (1999). A Multi-Country Comparison of the Drive for IMC, Journal of Advertising Research, Volume 39,p 21-38

15. Mc Cracken, G., 1986, "Culture and Consumption: a Theoretical Account of the Structure and Movement of the Cultural Meaning of Consumer Goods", Journal of Consumer Research, Vol. 13 No. 1, pp. 71;

16. Mick, D. and Buhl, C., 1992, "A Meaning-Based Model of Advertising Experiences", Journal of Consumer Research, Volume 19, Issue 3, p 317-338.

17. Morioka, S. N., Evans, S., Carvalho, M. M. (2016). Sustainable Business Model Innovation: Exploring Evidences in Sustainability Reporting, Procedia CIRP, Volume 40, p. 659-667

18. Pelsmacker, P. , Geuens, M. and Van den Berg, J., 2013, Marketing Communications: A European Perspective, 5th ed., Pearson, Harlow p73-75

19. Schultz D.E., Kitchen P. J. (2000). Communicating Globally: an Integrated Marketing Approach. London: Palgrave-Macmillan, p 16

20.Salkovska, J. (2016). Integrētā mārketinga komunikācija, Promocijas darba (monogrāfijas) kopsavilkums Doktora grāda iegūšanai ekonomikas nozarē, p 77

21. Seric, M., Gil Saura, I. and Ozretic Dosen, D.(2015). Insights on Integrated Marketing Communications: Implementation and Impact in Hotel Companies, International Journal of Contemporary Hospitality Management, Volume 27, p 958-979 